\title{
Innovating Science Teaching by Participatory Action Research - Reflections from an Interdisciplinary Project of Curriculum Innovation on Teaching about Climate Change
}

Timo Feierabend and Ingo EILKs ${ }^{* 1}$

$\approx$ This paper describes a three-year curriculum innovation project on teaching about climate change. The innovation for this study focused on a socio-critical approach towards teaching climate change in four different teaching domains (biology, chemistry, physics and politics). The teaching itself explicitly aimed at general educational objectives, i.e., fostering students' communication and evaluation abilities as essential components for preparing young people for active participation in society. Participatory Action Research has been used as a collaborative strategy of cyclical curriculum innovation and research. Using past experiences and selected results from accompanying research, this project and its methodology will be reflected upon from the viewpoint of the chemistry group taking part in the project. Core issues reflected upon include how the project contributed to the creation of feasible curriculum materials, how it led to innovative structures in practice, and whether it supported experienced teachers' ongoing professional development. General considerations for the process of curriculum innovation will also be derived.

Key words: Climate change, Curriculum innovation, Participatory action research, Science education

$1 \quad{ }^{\star}$ Coresponding author: University of Bremen - Department of Biology and Chemistry, Institute for the Didactics of the Sciences (IDN) - Chemistry Education, Leobener Str. NW2, 28334 Bremen, Germany ingo.eilks@uni-bremen.de 


\section{Teaching about climate change and science education}

Climate change has become one of the most dominant sciencerelated issues in today's political debate (e.g., Ekborg \& Areskoug, 2006). It can be considered - borrowing the words of Wolfgang Klafki (2000) - to be one of society's 'key problems of our epoch'. For Klafki, these 'key problems' represent the most promising issues for educators to employ in aiding their students to achieve Allgemeinbildung. Allgemeinbildung in this sense conceptualises the central goal of any contemporary education to help students better their capabilities in self-determination, political participation and solidarity with others in a democratic society (e.g., Hofstein, Eilks \& Bybee, 2011).

One typical characteristic of such key problems is that they are (still) undetermined to some degree. Although there is a huge body of literature published about the causes and potential effects of climate change (e.g., IPCC, 2007) there is still no consensus about the implications obtainable from the available data. This means we are faced with conflicting evidence and quite often contradictory opinions (e.g., Ekborg \& Areskoug, 2006; Hulme, 2009). Nevertheless, decisions must be reached on both the individual as well as the political levels (Ekborg \& Areskoug, 2006). Politics decides upon new regulations, e.g., the taxation of renewable energies, but each individual also continually makes relevant decisions, such as whether to drive one's own car or use public transport. The basis for many of these decisions is still undetermined, which makes climate change an interesting topic for contemporary education in general and for science education in particular. In the words of Sadler (2004): The most fruitful settings for science education are "those which encourage personal connections between students and the issues discussed, explicitly address the value of justifying claims and expose the importance of attending to contradictory opinions" (p. 523).

Unfortunately, nowhere is climate change education as successful as it should be (Rickinson, 2001). Deficits are reported in several areas, e.g., concerning students' understanding of the science of climate change and its possible impacts on society (e.g., Andersson \& Wallin, 2000; Boyes, Skamp \& Stanisstreet, 2009; Boyes \& Stanisstreet, 1993, 1997; Hansen, 2010), but this is not the full extent of the lacking factors. In very few lesson examples within science education literature is climate change even connected to the learning of the societal and political dimension of the issue. The societal orientation of science 
education as a whole often remains a far too neglected field (Hofstein et al., 2011). There seems to be a lack of proper strategies, materials, and their application. A recent survey of twenty German chemistry teachers' views on and experiences with teaching climate change made it clear that a reliable consensus among teachers as to when, how, and even in which school subject climate change should be taught is still lacking, at least in the case of German schools. Although all of the teachers asked supported the importance of learning about climate change, they themselves did not consider climate change an equally important issue for their curricula as compared to more traditional topics of chemistry education (Feierabend, Jokmin \& Eilks, 2011).

Based on these points, the project "The Climate Change Before the Court" was established. The project lasted a total of three years (2008-2011). It is a curriculum innovation and research project for teaching climate change in four different teaching domains: biology, chemistry, physics and politics (e.g., Eilks et al., 2011a; Feierabend \& Eilks, 2010). The project was funded by the German Environmental Foundation (DBU), and in 2009 it was awarded as an official German project of the UN World Decade of Education for Sustainable Development.

The project "The Climate Change Before the Court" seeks to develop and research different ways of implementing teaching about climate change in the three science subjects (biology, chemistry and physics) and also involves politics lessons as an external reference. The project attempts to pinpoint criteria for the Where and How of teaching climate change in common curricular structures in the sciences. This includes the societal point of view, the use of innovative structures, introducing student-oriented pedagogy, and focusing on students' evaluation and decision-making capabilities (Höttecke et al., 2010). As a common strategy, all school subjects selected the sociocritical and problem-oriented approach to science teaching (Marks \& Eilks, 2009) and employed role-playing exercises to enhance learning about how socio-scientific issues such as climate change are handled by society. The project was driven by the Participatory Action Research model of science education (Eilks \& Ralle, 2002), which represents a collaborative process of cyclical curriculum innovation and research.

In this paper, the research model and the structure of the project will both be presented. Reflection will include selected results from the accompanying research and the experiences of the participating chemistry group, including the project and research methodology. 


\section{Participatory Action Research for curriculum innovation in science education}

The tradition of using action research for classroom improvement and teachers' professional development is quite well-established for education in general and in science education in particular (e.g., Bencze \& Hodson, 1999; Feldman, 1996; Parke \& Coble, 1997). Differences in the forms of action research are mainly connected to questions of power and control. The processes of action and research can lean either to the researchers' or to the practitioners' side (Eilks \& Ralle, 2002; Eilks, Markic \& Witteck, 2010). In our case, we argue that applied academic educational research focusing on curriculum development in science education should have the goal of developing strategies and materials to potentially improve practices in as many learning groups as possible. Thus, we chose an interpretation of action research that is more general and researcher-centred. The approach adopts the idea of Participatory Action Research (PAR) as described by Whyte, Greenwood and Lazes (1989) for the field of economics and applies it to science education (Eilks \& Ralle, 2002). In this way, we outlined five equally important domains of objectives when using action research as a strategy for applied academic research (Fig. 1):

- The development of new concepts and materials for improving teaching and learning practices, including the evaluation and dissemination of the said strategies

- The attainment of empirical evidence on applied learning and teaching approaches within authentic teaching practice

- The development of concrete teaching practices involved in the process of deficit reduction

- In-service training of the practitioners involved pertaining to their self-awareness of how effectively they work, including improving their skills in curriculum development and evaluation

- Documentation of the settings and experiences as examples of good teaching practice

In order to reach these five objectives, the PAR research model for science education is described as a cooperative process of practitioners and accompanying scholars. This cooperative approach recognises the fact that empirically validated research results and experientially-based teacher knowledge represent the two extremes 
of the knowledge spectrum of teaching and learning, and both have their own strengths and are important in their own right (McIntyre, 2005). Thus, we build cooperation between practicing science teachers in schools and science educators from university. As dictated by the foundations of action research and its roots in critical theory, everyone involved has equal status and contributes to each of the decisions made during the whole research and development process.

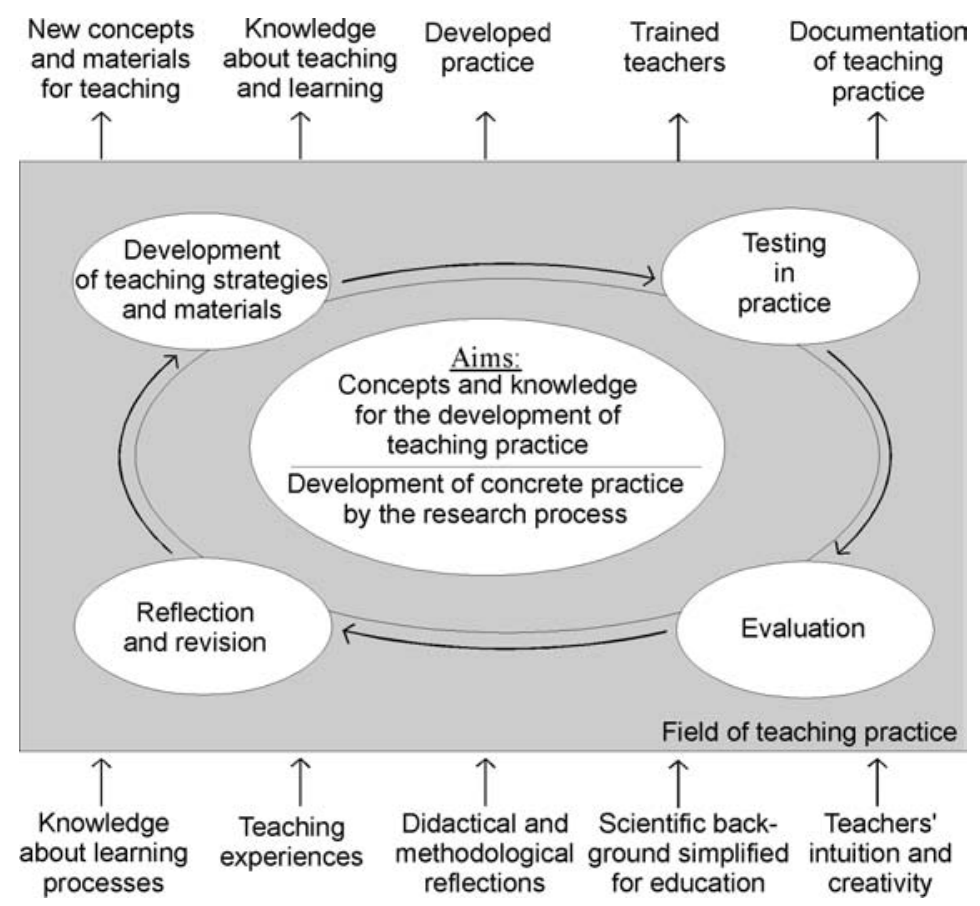

Figure 1. Participatory Action Research within domain-specific education (Eilks \& Ralle, 2002)

Although all members in the action research groups have equal status, it is more helpful to simply think of them as fulfilling different roles (Altrichter \& Gstettner, 1993). The "external" researchers focus on clarifying and structuring theoretical evidence as a basis for curriculum planning, justifying the changes from a theoretical perspective, organising the research process, and taking care of ethical and/ or methodological issues in the accompanying research. Participating teachers concentrate their efforts on translating the new methodological elements into effective teaching practice, testing the changed 
approaches and taking care of the feasibility of the efforts (Eilks \& Ralle, 2002; Eilks et al., 2010). Nevertheless, all decisions are made through the consensus of the entire group.

The PAR research process is initiated by reports of deficits in teaching practices, either from hands-on experience or from empirical educational research. This is the case concerning climate change, as has been documented in a whole series of studies (see above). PAR intends to find new ways to reduce the reported problems step-by-step. The process begins with a thorough analysis of the relevant literature, which is provided by the accompanying researcher. The analysis offers a starting point for group discussions by the researchers and teachers. It allows them to determine how - and if - the problem is authentic, of interest to the teachers, and potentially beneficial for improving teaching practices beyond the individual classroom. The discussions also focus upon the evidence from the scientific literature and whether the teachers consider it to be of value for the specific educational setting in which they work. This process ensures that any strategies developed are relevant to the teachers for problems found in their own authentic classroom practices. Additional input comes from analysis of the scientific background and its integration into educational purposes, as well as from the personal experience, intuition and creativity of researchers and practitioners alike (Fig. 1).

Just like every kind of Action Research, the process of development is cyclical. New teaching materials and strategies are designed. These initial designs are used and tested as early as possible in order to see if they can potentially solve the problems being addressed. The lesson plans are then improved stepwise in ongoing cycles of testing, evaluation, self-reflection and restructuring (Fig. 1). During this cyclical refinement of teaching strategies, the perspectives of all participants (teachers, students, and researchers) are taken into consideration using a multi-perspective approach of evaluation (Eilks \& Ralle, 2002). However, evaluation tools and strategies being selected as appropriate for application in authentic teaching practice usually means that, in most cases, smaller and more focused evaluation tools have been combined into a multi-perspective, triangular approach. Despite these restrictions, a whole set of different methods suggest themselves, e.g., group discussions among the practitioners, open and standardised questionnaires for the students, audio and video clips from the classrooms, personal classroom observations, analysis of student artefacts, and sample interviews with either students or teachers. 
For analysis of the data, Bodner, MacIsaac and Whyte (1999) suggest that classical philosophies applying a quantitative understanding of evaluation are not appropriate for this kind of curriculum development. They warn us that far too many outside influencing factors cannot be controlled in a reliable fashion. Another reason for not applying positivistic-based philosophies of data interpretation is that both researchers and practitioners are personally involved in developing and carrying out the practices. This means that a qualitative, interpretative paradigm of research is much more suitable for PAR-type research. Nevertheless, findings must meet quality control criteria. Therefore, the validity of the interpretations is tested by communicative validation with the teachers. Altheide and Johnson's (1994) criteria for interpretative research can be used for this: plausibility, credibility, relevance and importance.

\section{Methodology and objectives of the project "The Climate Change Before the Court"}

'Climate Change Before the Court' represents interdisciplinary cooperation among educators and practitioners in the fields of chemistry, biology, physics, and political education (Eilks et al., 2011a). In addition to the university and roughly twenty different schools, some ten additional partners come from the informal sector of science education, e.g., a science centre dealing with the issue of climate, a museum of regional natural history and regional centres for informal environmental education.

In the course of the project, one group of Participatory Action Research was established for each of the four school subjects, namely Biology, Chemistry, Physics, and Politics. Each group was composed of 5-8 teachers accompanied by 1-2 domain-specific university educators from the respective field of study. The teachers came from different schools in the north of Germany and represented teaching practices in middle, grammar and comprehensive schools in both rural and municipal areas.

The groups structured their lesson plans over a time period of about two years. On average they met once a month for one afternoon in order to structure the lesson plans and materials and to report on and discuss their experiences. The meetings were also used to acquaint the teachers with current scientific information on the issue of climate change. Participants increased their knowledge of available 
curriculum materials and potential school-type experiments from the scientific literature, which worked as inspiration for their curriculum planning efforts.

Objectives of the project included:

- The development of lesson plans for teaching climate change with a special focus on strengthening students' communication, evaluation and decision-making capabilities with the inclusion of a societal perspective;

- Implementing the lesson plans into practice, researching their feasibility and effects, and helping teachers in their professional development concerning the application of the respective teaching strategies; and

- Conducting accompanying research on how to deal with the challenge of climate change in domain-specific cultures among educators working in the different science teaching domains.

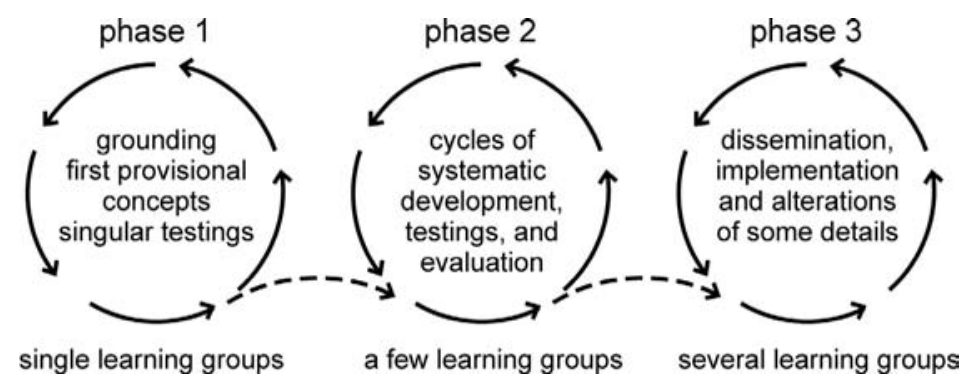

Figure 2. The three phases of the development process in PAR (Eilks \& Ralle, 2002)

Following the three-phase model of PAR (Fig. 2), the lesson plans as whole - or single elements thereof - were individually pretested by members of the group. Broader testing took place after the first full proposal of each of the lesson plans was ready. In this phase, the lesson plans were taught parallel to one another in all four subjects. Five different learning groups tested each lesson plan and represented a good blend of middle, grammar and comprehensive school classes from northern Germany. These twenty groups in the main testing cycle led to feedback from a total of 432 students. Student feedback was collected using questionnaires containing both open and Likert-based items. Additionally, pre- and post-group discussions were conducted 
in all learning groups. Both approaches focused upon lesson plan feasibility, students' viewpoints concerning climate change, and learner self-reflection on the decision-making process within the lesson plan. For later analysis of the course of the process, teacher feedback was also monitored by videotaping every action research group meeting. All data was then evaluated using qualitative content analysis (see Mayring, 2002).

Additional data was collected in order to better understand not only the domain-specific cultures of how to deal with evaluation competency, but also the changes in teachers' pedagogical content knowledge. Data from these studies are currently under evaluation and will not to be discussed in this paper.

\section{The teaching approach within the project "The Climate Change Before the Court"}

Within the project "The Climate Change Before the Court", designing the lesson plans for each subject was inspired by the sociocritical and problem-oriented approach to science teaching (Fig. 3) as originally developed by Eilks $(2000,2002)$ for chemistry education. The actual model applied was then refined to its present form using a whole series of examples over the last ten years (e.g., Marks \& Eilks, 2009). This pattern for societal and multidimensional-oriented science education organises lessons using a five-step model. The lessons start with a current, controversial socio-scientific issue, which is presented to the students using current, authentic media (e.g., newspapers or TV). All lesson plans incorporate a second phase of learning that addresses the essential scientific background necessary for understanding at least the basics of the relevant socio-scientific issue. After this the socio-scientific debate is resumed. The central phase of learning about both society's handling of the issue and the inherent interplay between science and society is constructed by mimicking authentic societal practices. In the case of this project, a joint decision was made to apply either role-playing or a business game in this step of teaching, since this had already proved to be of value in a related pilot study on bioethanol use (Feierabend \& Eilks, 2010, 2011). The lesson plans finish with meta-reflection, which focuses on the method, performance, and learning process themselves, rather than simply on the topic and its evaluation. 
Concept of the socio-critical and problem-oriented approach to science teaching

\begin{tabular}{|c|c|c|c|}
\hline Objectives & $\begin{array}{l}\text { Criteria for selecting } \\
\text { issues and apporaches }\end{array}$ & Methods & $\begin{array}{c}\text { Structure of the lesson } \\
\text { plans }\end{array}$ \\
\hline $\begin{array}{l}\text { Allgemeinbildung/ } \\
\text { education through } \\
\text { science }\end{array}$ & Authenticity & Authentic media & $\begin{array}{l}\text { 1. Textual approach and } \\
\text { problem analysis }\end{array}$ \\
\hline $\begin{array}{l}\text { (Multidimensional) } \\
\text { Scientific Literacy }\end{array}$ & Relevance & $\begin{array}{c}\text { Student oriented } \\
\text { chemistry learning and } \\
\text { lab-work }\end{array}$ & $\begin{array}{l}\text { 2. Clarifying the } \\
\text { chemistry background } \\
\text { in a lab environment }\end{array}$ \\
\hline $\begin{array}{l}\text { Promotion of } \\
\text { evaluation skills }\end{array}$ & $\begin{array}{c}\text { Evaluation } \\
\text { undetermined in a } \\
\text { socio-scientific respect }\end{array}$ & $\begin{array}{l}\text { Learner centred } \\
\text { instruction and } \\
\text { cooperative learning }\end{array}$ & $\begin{array}{l}\text { 3. Resuming the socio- } \\
\text { scientific dimension }\end{array}$ \\
\hline $\begin{array}{c}\text { Promotion of } \\
\text { communication skills }\end{array}$ & $\begin{array}{l}\text { Allows for open } \\
\text { discussion }\end{array}$ & $\begin{array}{l}\text { Methodsstructuring } \\
\text { controversial debating }\end{array}$ & $\begin{array}{l}\text { 4. Discussing and } \\
\text { evaluating different } \\
\text { points of view }\end{array}$ \\
\hline Learning science & $\begin{array}{l}\text { Deals with questions } \\
\text { from science and } \\
\text { technology }\end{array}$ & $\begin{array}{c}\text { Methods provoking the } \\
\text { explication of individual } \\
\text { opinions }\end{array}$ & 5. Meta-reflection \\
\hline
\end{tabular}

Figure 3. Conceptual framework of the socio-critical, problemoriented approach to science teaching (Marks \& Eilks, 2009).

Table 1 gives an overview of the four lesson plans. The chemistry group's teaching example has already been described in more detail in Feierabend and Eilks (2010). All teaching materials have been completed and will soon be published as a resource book for teachers interested in teaching climate change in science classes, including those using interdisciplinary and project-based teaching approaches (Eilks et al., 2011b). Upon completion of the project, parts of the materials were adopted for use by the partners from the informal educational domain. For example, the materials focusing on socio-scientific reflection about climate change are now being applied by these participants as an accompaniment to more content-focused offers already existing in their exhibition programmes. 
Table 1. Overview of the lesson plans from the various projects (Eilks et al., 2011a)

\begin{tabular}{|c|c|c|c|}
\hline & Textual approach & Science content & Role-playing scenario \\
\hline Biology & $\begin{array}{l}\text { Authentic magazine } \\
\text { cover and article }\end{array}$ & $\begin{array}{l}\text { Internet search and } \\
\text { jigsaw classroom on the } \\
\text { relationship between } \\
\text { food production and the } \\
\text { emission of greenhouse } \\
\text { gases }\end{array}$ & $\begin{array}{l}\text { Role-playing a school's } \\
\text { decision not to offer } \\
\text { meat dishes anymore } \\
\text { in the school cafeteria }\end{array}$ \\
\hline Chemistry & $\begin{array}{l}\text { Satirical YouTube } \\
\text { video on the effects } \\
\text { of climate change }\end{array}$ & $\begin{array}{l}\text { Jigsaw classroom and } \\
\text { experimental learning- } \\
\text { at-stations lab on the } \\
\text { use of conventional and } \\
\text { renewable fuels for cars } \\
\text { and their comparison }\end{array}$ & $\begin{array}{l}\text { Role-playing/business } \\
\text { game on raising the } \\
\text { minimum driving } \\
\text { license age to } 21 \text { years } \\
\text { in order to reduce the } \\
\text { number of potential } \\
\text { car drivers }\end{array}$ \\
\hline Physics & $\begin{array}{l}\text { Scientific } \\
\text { presentation on } \\
\text { climate change and } \\
\text { its potential effects }\end{array}$ & $\begin{array}{l}\text { Experimental learning- } \\
\text { at-stations lab on heat } \\
\text { absorption by gases, } \\
\text { the radiation budget of } \\
\text { the earth, and effects of } \\
\text { temperature rises in the } \\
\text { atmosphere }\end{array}$ & $\begin{array}{l}\text { Role-play/business } \\
\text { game on measures } \\
\text { against the import } \\
\text { of fruits brought } \\
\text { to Europe by air } \\
\text { transportation }\end{array}$ \\
\hline Politics & $\begin{array}{l}\text { TV report on } \\
\text { the competition } \\
\text { between food and } \\
\text { fuel production }\end{array}$ & $\begin{array}{l}\text { Reading informative texts } \\
\text { about essential elements of } \\
\text { the science background }\end{array}$ & $\begin{array}{l}\text { Business game on } \\
\text { establishing an } \\
\text { embargo on the } \\
\text { import of Brazilian } \\
\text { bioethanol }\end{array}$ \\
\hline
\end{tabular}

\section{Selected aspects of the accompanying research}

In the teacher discussions during the PAR group meetings, the deficiencies mentioned in the literature (see above) were supported by the participants, including the facets dealing with individual school environments. The teachers generally acknowledged the importance of this issue, but also affirmed a lack of adequate teaching materials. In line with the literature reviews, some teachers also mentioned feelings of insecurity when teaching climate change themselves, since they did not feel sufficiently confident in their content matter knowledge. The reason stated by the teachers was their awareness of climate change's undetermined nature as an issue and uneasiness at dealing with various contradictory interpretations found in the public debate. They also 
stressed that their formal training as science teachers took place long before climate change ever became an issue of concern. Furthermore, in-service trainings focusing on multidimensional approaches to climate change were not available at that time. Teachers also felt a lack in sufficient support from textbooks and teaching materials. Here, they expressed their appreciation of the course the project took. The university input given as an update to their knowledge was very wellreceived, including not just the information about content but also that dealing with available pedagogies and school-type experiments.

The teachers' participation in the project was acknowledged as being of great value. From the teachers' viewpoint, this project resulted in highly feasible teaching materials that they enjoyed including in their regular teaching. The teachers felt that the help from the university was very valuable for the joint development of new teaching materials, but they also expressed satisfaction that their influence on the structure of the teaching materials had been acknowledged. Also, the involvement of different types of schools (grammar, middle and comprehensive schools from both rural and municipal areas) in the two subjects where this was the case (biology and chemistry) was considered to be beneficial because this led to continuous reflection upon how the materials could be as broadly applicable as possible. In the end, the teachers felt better prepared to cope with difficult issues like climate change in their given subjects. Many of the teachers asked for further cooperation on both related and new issues. Altogether, the teachers reported a growth of personal expertise in the areas of content, methodology, and using experimental work in the classroom.

Concerning the lesson plans, the teachers reported classes that were highly student-active. The developed lesson plans were thought to be an enrichment of the pedagogies that the teachers normally applied. Student feedback on the lesson plans was also very positive. In the case of the chemistry questionnaire, pupils were asked about the lesson plan itself and their perceptions of it (see also Feierabend \& Eilks, 2010). Nearly $70 \%$ of the students completely or predominantly agreed that they had enjoyed the lesson plan because it dealt with content that personally interested them. A further $20 \%$ agreed partially to this same statement. Nearly $70 \%$ of the pupils agreed that they really liked the lesson plan's methods (again with about $20 \%$ agreeing partially) because learners could work out answers together with their classmates. Most students liked the business game element as part of science teaching, although this aspect is very unconventional in German 
science classrooms. Total agreement for this item was above 50\% and partial agreement a further $25 \%$. The results were similar in the other three subjects with only slight variation. In the open questionnaire, too, which was filled out before the Likert questionnaire, over $70 \%$ gave positive feedback on their own choices concerning different aspects of the lesson plan, i.e., the applied pedagogies.

From the point of view of the students, the lesson plans made them think more about climate change, with nearly $70 \%$ of the students at least predominantly agreeing with such a statement (and another $25 \%$ partially agreeing). The chemistry students came predominantly from grade 9 comprehensive and middle school classes. Agreement was slightly lower in the other subjects, which were dominated by $10^{\text {th }}$ grade grammar school classes. Perhaps the higher-achieving, older students in these courses felt themselves to be more self-reflective on this topic prior to the lesson plan. Nevertheless, even among these groups between $45 \%$ (biology) and 6o\% (physics) of the learners positively replied to this item, with another $30 \%$ in both groups agreeing at least partially. Other items on this issue, e.g., whether students now saw the media debate with different eyes or whether their personal viewpoint towards climate change had altered, were also supported by roughly half of the pupils, with variations in the different subjects. Partial support was expressed by another $30 \%$ of the participants.

Looking at the group discussion results, we can recognise initial trends in the present state of the data analysis. In both the pre-group and post-group discussions, students recognised their responsibility for climate change on different levels (personal, political and economic). They saw a plurality of countermeasures for each level, even though the manner of argumentation differed quite widely (spontaneous vs. justified, reflective or constructive). Students were confronted with two dilemmas during the discussions: 1) a German city where pupils are forbidden to come to school by car (pre-discussion group) and 2) an EU-wide ban on conventional light bulbs, including their immediate replacement with energy-saving lamps (post-discussion group). Learners were asked to list pros and cons for each situation, which decision-makers might be included and to state their own ideas of how such decisions should be handled. Starting with these two scenarios, intense discussions occurred in all of the groups. Overall, pregroup discussion was dominated by spontaneous, personal and often poorly-justified arguments. In the post-group discussions, the number of well-reflected and evidence-based arguments increased slightly. A 
more detailed analysis of the levels of argumentation is currently underway. Although one can hardly expect a single lesson plan of roughly 10 periods to cause a measurable increase in students' argumentative capabilities, evaluation skills and decision-making processes, preliminary indicators reveal that at least a small rise in students' skill development took place.

\section{Reflection, discussion and implications}

The reflection on this project should focus on two different points: 1) the outcome of the project concerning teaching and curriculum materials, and 2) the PAR method, i.e., its potential for both curriculum and teachers' ongoing professional development.

Concerning teaching about climate change, the different PAR groups clearly supported the theoretical analysis that this issue has high potential for promoting student capabilities in communication, evaluation and decision-making. The joint reflection on the research evidence and teachers' classroom experience was valuable for making teachers aware of both their own deficits and restrictions and also their interests and needs. This was an important starting point for sustainable innovation, since Huberman (1993) has already stated that any sustainable innovation in education must be bound to personal experience. In this case, it began with reflection on teachers' personal past experiences and was continuously linked to new experiences based on the newly-developed teaching approaches.

The teachers also agreed that the units showed promise for dealing with climate change in science education in a multidimensional fashion. Results from both teacher and student feedback show that this potential was beginning to be realised in the initial steps. The collaborative and cyclical design plan led - in the estimation of the teachers and educators - to highly feasible, motivating lesson plans. Both the theoretical input from the accompanying educator as well as the practical experience of the teachers contributed to the overall quality of the curriculum materials.

Within this project, two additional features were borrowed from other PAR projects in chemistry education in the past (e.g., Marks \& Eilks, 2009; Eilks et al., 2010). One was the interdisciplinary approach and the other was the inclusion of partners from the informal educational domain. Compiling the results and bringing the teachers from the four groups together also clearly showed the need for 
interdisciplinary approaches towards complex issues such as climate change. Nevertheless, initially working in parallel teams then networking the different viewpoints and results proved to be a good strategy. It 1) allowed each group to become clear about their experiences and interests and 2) led to lesson plans feasible for individual syllabuses in individual subjects where administrative restrictions do not allow for interdisciplinary teaching (e.g., Feierabend \& Eilks, 2010). Nevertheless, the end product was a set of materials that can be combined in different ways for interdisciplinary or project-based approaches (Eilks et al. 2011b). The materials are now ready to integrate the science subjects under the inclusion of a societal point of view. This provides a basis for new teaching strategies on climate change in German science education classrooms. The inclusion of politics also helped a great deal, since this opened the project's focus and employed political pedagogies that also show promise for the area of science education. These experiences clearly support the idea that climate change as an issue requires a subject-integrated approach. This includes not just a combination of the different science teaching domains but also other relevant subjects such as politics, education, geography and other fields in the humanities. Educational policy should take care not to restrict the teaching of complex issues with more holistic approaches due to administrative barriers. This includes the overly thorough compartmentalising of education by strictly dividing it into different school subjects and their respective syllabuses. On the other hand, the inclusion of partners from the informal educational domain did not have much influence on the curriculum development process within the project. However, we can recognise its still largely untapped potential for 1) increasing levels of exchange and cooperation between (in)formal education concerning curriculum development and 2) better educational networking and fine tuning in both schools and informal education. Nevertheless, the inclusion of informal education partners gave us a second platform for the implementation of part of the materials developed.

With respect to the teachers' professional development, the issue of climate change proved to be difficult to cover. It is very uncommon for science teachers to deal with issues characterised by uncertainty, e.g., the continuous changes in scientific interpretations of available data or rapidly changing political debates, although such aspects are quite commonly dealt with by teachers of politics. Nonetheless, the science teachers felt able to cope with this challenge, thanks to the support of their diverse network of colleagues from different 
domains. Based on this experience, educational policy should provide stronger support to such multidimensional networks. It can acknowledge participation in such networks, for example by compensating the teachers with downtime for the time they spend working on project activities. Unfortunately, this was not the case for most of the teachers in this project, who had to sacrifice their time on a voluntary basis. PAR proved to be a potentially beneficial structure for supporting such networking.

As part of teachers' continuous professional development our experiences with PAR support the findings of similar projects, e.g., concerning the implementation of cooperative learning in chemistry education (Eilks et al., 2010) or the socio-critical, problem-oriented approach to chemistry teaching (Marks \& Eilks, 2010). The value of PAR lies in its leading to a variety of lesson plans. These plans are widely accepted by teachers as being authentic, well-tested and feasible, as we observed for the current examples of climate change lessons within this project. Furthermore, PAR also contributed to teachers' $\mathrm{CPD}$ in the sense that it caused changes in the teachers' knowledge base, skills and attitudes, as previously reported in Eilks (2003) and Eilks et al. (2010). The respective indications were also found within this framework.

New perspectives on PAR from this project included 1) parallel application in different teaching domains and increasing integration and 2) the inclusion of partners from informal science-related education. The first addition to the previous PAR framework in chemistry education had great value, both for the quality of the developed materials as well as for expanded opportunities for teachers' CPD. Conversely, the presence of informal educational partners did not influence the project much. Perhaps more thorough integration with this domain may uncover further potential in such cooperation.

For sustainable innovations in science education curricula and practice we can recognise the overall value of establishing researchbased networks for close cooperation between educational researchers and practising teachers. Such partnerships are also operationalised in other approaches and methodologies (see Putnam \& Borko, 2000). Here, they proved to us once again that both sources of information about teaching practice are invaluable. Empirically validated research results and experientially-based teacher knowledge represent the two extremes of a knowledge spectrum describing teaching and learning, and both are equally important in their own right (McIntyre, 2005). 
For educational policy, this and similar projects (e.g., Eilks et al., 2010; Marks \& Eilks, 2009) yield clear support for our idea that more research-oriented partnerships between curriculum developers, educational researchers, and practising teachers should be established. This would allow us to make use of all of the resources that are available for teaching practice innovation in a networked environment. PAR as a research design may help to uncover further potential for sustainable reform and implementation. These are due to the fact that teachers' beliefs, their a priori knowledge and personal attitudes are all involved in such reforms and are taken into account seriously by the project. This is one of the essential basics for any successful, meaningful innovation in teaching practice, as has already been discussed by Haney, Czerniak and Lumpe (1996) or Huberman (1993).

\section{Acknowledgement}

We thank the Deutsche Bundesstiftung Umwelt DBU (German Federal Trust for Environment) for their generous funding of this project.

\section{References}

Altheide, D., \& Johnson, J. (1994). Criteria for Assessing Interpretative Validity in Qualitative Research. In N. Denzin \& Y. Lincoln (Eds.), Handbook of Qualitative Research (pp. 485-499). Newsbury Park: Sage.

Altrichter, H., \& Gstettner, P. (1993). Action Research: A Closed Chapter in the History of German School Science. Educational Action Research, 1, 325-360.

Andersson, B., \& Wallin, A. (2000). Students' Understanding of the Greenhouse Effect, Social Consequences of Reducing $\mathrm{CO}_{2}$ Emissions and Why Ozone Layer Depletion is a Problem. Journal of Research in Science Teaching, 37, 1096-1111.

Bencze, L., \& Hodson, D. (1999). Changing Practice By Changing Practice: Toward More Authentic Science and Science Curriculum Development. Journal of Research in Science Teaching, 36, 521-539.

Bodner, G., MacIsaac, D., \& White, S. (1999). Action Research: Overcoming the Sports Mentality Approach to Assessment/Evaluation. University Chemistry Education, 3(1), $31-36$.

Boyes, E., Skamp, K., \& Stanisstreet, M. (2009). Australian Secondary Students' Views About Global Warming: Beliefs About Actions, and Willingness to Act. Research in Science Education, 39, 661-680.

Boyes, E., \& Stanisstreet, M. (1993). The Greenhouse Effect: Children's Perceptions of Causes, Consequences and Cures. International Journal of Science Education, 15, 531-552.

Boyes, E., \& Stanisstreet, M. (1997). Children's Models of Understanding of Two Major 
Global Environmental Issues (Ozone Layer and Greenhouse Effect). Research in Science \& Technological Education, 15, 19-28.

Eilks, I. (2000). Promoting Scientific and Technological Literacy: Teaching Biodiesel. Science Education International, 11(1), 16-21.

Eilks, I. (2002). Teaching 'Biodiesel': A Socio-Critical and Problem-Oriented Approach to Chemistry Teaching, and Students' First Views on It. Chemical Education: Research and Practice in Europe, 3, 67-75.

Eilks, I. (2003). Cooperative Curriculum Development in a Project of Participatory Action Research Within Chemical Education: Teachers' Reflections. Science Education International, 14(4), 41-49.

Eilks, I., Feierabend, T., Hößle, C., Höttecke, D., Menthe, J., Mrochen, M., \& Oelgeklaus, H. (2011a). Bewerten Lernen und Klimawandel in vier Fächern - Erste Einblicke in das Projekt „Der Klimawandel vor Gericht“. Der Mathematische und Naturwissenschaftliche Unterricht, 64, 7-11 and 71-76.

Eilks, I., Feierabend, T., Hößle, C., Höttecke, D., Menthe, J., Mrochen, M., \& Oelgeklaus, H. (2011b). Der Klimawandel vor Gericht - Unterrichtmaterialien für den Fachunterricht und fächerübergreifende Projekte. Köln: Aulis-Starck in print.

Eilks, I., Markic, S., \& Witteck, T. (2010). Collaborative Innovation of the Science Classroom by Participatory Action Research - Theory and Practice in a Project of Implementing Cooperative Learning Methods in Chemistry Education. In M. Valenčič Zuljan, \& J. Vogrinc (Eds.), Facilitating Effective Student Learning Through Teacher Research and Innovation (pp. 77-101). Ljubljana: University of Ljubljana.

Eilks, I., \& Ralle, B. (2002). Participatory Action Research in Chemical Education. In B. Ralle, \& I. Eilks (Eds.), Research in Chemical Education - What does this mean? (pp. 8798). Aachen: Shaker.

Ekborg, M., \& Areskoug, M. (2006). How Student Teachers' Understanding of the Greenhouse Effect Develops During a Teacher Education Programme. NorDiNa - Nordic Studies in Science Education, 5, 17-29.

Feierabend, T., \& Eilks, I. (2010). Raising Students' Perception of the Relevance of Science Teaching and Promoting Communication and Evaluation Capabilities Using Authentic and Controversial Socio-Scientific Issues in the Framework of Climate Change. Science Education International, 21, 176-196.

Feierabend, T., \& Eilks, I. (2011). Teaching the Societal Dimension of Chemistry Along a Socio-Critical and Problem-Oriented Lesson Plan on the Use of Bioethanol. Journal of Chemical Education, accepted for publication.

Feierabend, T., Jokmin, S., \& Eilks, I. (2011). Chemistry Teachers' Views on Teaching 'Climate Change' - An Interview Case Study From Research-Oriented Learning in Teacher Education. Chemistry Education Research and Practice, 11, 85-91.

Feldman, A. (1996). Enhancing the Practice of Physics Teachers: Mechanisms for the Generation and Sharing of Knowledge and Understanding in Collaborative Action 
Research. Journal of Research in Science Teaching, 33, 513-540.

Haney, J. J., Czerniak, C. M., \& Lumpe, A. T. (1996). Teacher Beliefs and Intentions Regarding the Implementation of Science Education Reform Strands. Journal of Research in Science Teaching, 33, 971-993.

Hansen, P. J. K. (2010). Knowledge about the Greenhouse Effect and the Effects of the Ozone Layer Among Norwegian Pupils Finishing Compulsory Education in 1989, 1993 and 2005 - What Now? International Journal of Science Education, 32, 397-419.

Hofstein, A., Eilks, I., \& Bybee, R. (2011). Societal Issues and their Importance for Contemporary Science Education: A Pedagogical Justification and the State of the Art in Israel, Germany and the USA. International Journal of Science and Mathematics Education, published online January 2011.

Hulme, M. (2009). Why We Disagree about Climate Change. Understanding Controversy, Inaction and Opportunity. Cambridge: Cambridge University Press.

IPCC (2007). Climate Change 2007 - The Physical Science Basis. Cambridge: Cambridge University Press.

Höttecke, D., Hößle, C., Eilks, I., Menthe, J., Mrochen, M., Oelgeklaus, H., \& Feierabend, T. (2010). Judgment and Decision-Making about Socio-Scientific Issues: A Fundament for a Cross-Faculty Approach Towards Learning about Climate Change. In I. Eilks, \& B. Ralle (Eds.), Contemporary Science Education (pp. 179-192). Aachen: Shaker.

Huberman, M. (1993). Linking the Practitioner and Researcher Communities for School Improvement. School Effectiveness and School Improvements, 4, 1-16.

Klafki, W. (200o). The Significance of Classical Theories of Bildung for a Contemporary Concept of Allgemeinbildung. In I. Westbury, S. Hopmann, \& K. Riquarts (Eds.), Teaching as Reflective Practice. The German Didaktik Tradition (pp. 85-107). Mahwah: Lawrence Erlbaum.

Marks, R., \& Eilks, I. (2009). Promoting Scientific Literacy Using a Socio-Critical and Problem-Oriented Approach in Chemistry Education: Concept, Examples, Experiences. International Journal of Environmental and Science Education 4, 131-145.

Marks, R., \& Eilks, I. (2010). Research-Based Development of a Lesson Plan on Shower Gels and Musk Fragrances Following a Socio-Critical and Problem-Oriented Approach to Chemistry Teaching. Chemistry Education Research and Practice, 11, 129-141.

Mayring, P. (2002). Qualitative Content Analysis - Research Instrument or Mode of Interpretation? In M. Kiegelmann (Ed.), The Role of the Researcher in Qualitative Psychology (pp. 139-148). Tübingen: Ingeborg Huber.

McIntyre, D. (2005). Bridging the Gap between Research and Practice. Cambridge Journal of Education, 35, 357-382.

Parke, H. M., \& Coble, C. R. (1997). Teachers Designing Curriculum as Professional Development: A Model for Transformational Science Teaching. Journal of Research in Science Teaching, 34, 773-790.

Putnam, R. T., \& Borko, H. (200o). What do New Views of Knowledge and Thinking 
Have to Say about Research on Teacher Learning? Educational Researcher, 29, 4-15. Rickinson, M. (2001). Learners and Learning in Environmental Education: A Critical Review of the Evidence. Environmental Education Research, 7, 207-316.

Sadler, T. D. (2004). Informal Reasoning Regarding Socio-Scientific Issues: A Critical Review of Research. Journal of Research Science Teaching, 41, 513-536.

Whyte, W. F., Greenwood, D. J., \& Lazes, P. (1989). Participatory Action Research. The American Behavioural Scientist, 32, 513-551.

\section{Biographical note}

Timo Feierabend studied chemistry, mathematics and education for becoming a teacher in German grammar schools. He currently is in the final stage of doing his $\mathrm{PhD}$ in chemistry education in the Institute for Science Education (IDN) at the University of Bremen (Germany).

INGO EILKS was originally a grammar school teacher of chemistry and mathematics. He is now the head of the chemistry education group in the Institute for Science Education (IDN) at the University of Bremen (Germany). His research interests compass Action Research in Science education, research on science teachers' cognition, teaching the particulate nature of matter, and society oriented approaches in science education. 